\title{
Dimensions Construction of Institutional Norms for Place Branding
}

\author{
Weihong Zhao, Fan Zhang \\ Business School, Jiangxi Normal University, PR China
}

\begin{abstract}
The rapid development of economic globalization makes place branding become the strategic choice of place economic development, but modern enterprises in pursuit of economic interests ignores the collective interests, violate the institutional norms, and thus hinder the development of place branding. This study will explore what are the institutional norms for place branding based on institutional theory, and the dimensions construction of institutional norms for place branding.
\end{abstract}

\section{INSTRUCTION}

The rapid development of economic globalization intensifies the competition between places. To keep competitive strengths sustainably, a large number of place brands, as industry clustered and place symbolized, are rising from different places. For example, "Third Italy" in the 1970s, "Silicon Valley Electronics" in California, and "Chinese Yiwu Small Commodity" are place brands which are worldwide famous. With their strong brands' assets, place marketing attractiveness and place competitive strengths are strengthened (Zaichkowsky et al., 2010; Rahbar \& Wahid, 2011). However, place brands, different from those products or corporation brands that have definite property ownership, belong to public brands. Companies in the place abuse the place brand, violate social law and morality because of their public attribute. For example, "the storm of horsemeat" damages the reputation of European brands; the "hogwash oil" event makes Taiwan's brand image suffer great damages. Based on those examples, it is discovered that the development of place branding is of benefit to strengthen the overall advantages of place economy. While from the point of social benefit, if the companies violate social law and morality, the overall advantages of place brands can also be damaged.

The nature of place branding is a process of place institutionalization. It continually accepts and adopts methods that is widely approbated to set goals and chooses proper action to achieve goals---maximize economic benefit and social benefit. Place branding also shows the institution level of harmonious development among economy, society, environment in one district. Scott (1995) considers that the institution consist of the regulation, normalization and cultural cognition that provide stable significance for social life and related activities, resources. The normative factors emphasize moral responsibility basis of legal assessment at deeper level. It is easier to be internalized by actor compared to the regulative factors. Normative driving forces mainly express prescriptive, appreciable, and necessary content which is incorporated into social experience rules, standard procedures and professional standards, etc, and lead the activities, belief of organizations in the form of social responsibility and professionalization. Compared with the cultural cognitive factors, normative factors accord with shared code of morality and values based on the evaluation of normative legitimacy. Thus, when taking branding as a strategic choice for place development, the internal conformity of institutional norms will become the intrinsic motivation for place branding (Scott, 2005), guiding the companies behavior doing things right.

Institutional norms are important part of the institutional theory, as one of the three pillars of institutional theory. However, antecedent literatures haven't completely explained that what are the institutional norms, and even what are the institutional norms for place branding under the institutional environment. Besides, exploring the dimensions construction of the institutional norms is scarce, and lack of awareness and mining of dimensions composition of institutional norms for place branding. Therefore, this study will explore what are the institutional norms for place branding, and recognize the dimensions of institutional norms for place branding.

\section{THEORETICAL BACKGROUND}

\section{A. Place Branding}

Kotler et al. (1993) made the concept of place brands firstly and clearly, and used "Place branding" to represent the place branding (Kotler, 2002). Place branding is public branding activities which are named by geographical area collectively, but place is not limited to a particular place or administrative-level categories, including countries, places and cities, etc. (Maheshwari et al., 2011). The brand of a place is always complex and controversial. It is complicated by the identity of the place which is the condensation of historical, political, religious and cultural heritage (Govers and Go, 2009). It should be stressed that, the "place" refers to the geographic places with common characteristics and features. It may be the administrative area, the micro place and cross-border places, also be macroscopic place, followed by the functional boundaries rather than administrative boundaries or place boundaries.

From the antecedent literature, the academic have not reached consensus concept of place branding. Rainisto (2003) considers that the place branding is the additional attraction of a place, and the core is to build recognition. Kavaratzis (2005) sees that the place branding is to connect 
the function, emotion, relationship and strategy elements of a place together for the public and then form a series of unique association process. Allen (2007) definite the concept based on the concept of the company's brand as the products or services branding under the political or geographical framework. Anholt (2010) defines the place branding as a method to strengthen brand image and behavior to make the place famous. Kaplan et al. (2010) put the place branding as the appropriate marketing strategies to distinguish a city, place or country from its competitors in the economic, social, political and cultural distinction between practices. Therefore, place branding is the brand extension of product brand and the company brand, having a place identity and brand characteristics.

\section{B. Institution and Institutional Norms}

Meyer and Rowan (1977) first proposed the new institutional theory, believing that the study of organizational behavior should consider the institutional environment, more emphasis on the role of the organization running background. The organization is not only embedded in the organization's environment, but also is penetrated and constructed by the environment. Later, Meyer and Scott (1983) defined more clearly institutional environment in organization's environment, pointing out the institutional environment is a necessary condition for rules and organization to achieve legitimacy and support from the environment. Scott (1987) further suggested that institutionalized belief system, rules and roles is the foundation for individuals and organizations to survive and develop.

Norms are a social institution level context, referring to some of the beliefs, values, social norms, assume, etc. which are enjoyed by society, and through a number of social obligations and social expectations to guide behavior, not only from the utilitarian angle to act, but out of the inner beliefs and values (DiMaggio \& Powell et al., 1983). Scott (1995) believes that institutional norms are conventional, appreciable and obligatory dimensions in social life. Enterprises followed institutional norms are to get their legitimacy. The normative conformity of enterprises legitimacy arises from values of sharing, prescriptive nature, knowledge of identity, role positioning of task (Pederson, 2004). Chuhong Zeng (2008) judge the legitimacy of organizations is based on whether the organization's actions promote social welfare, whether meets the widely-accepted social values and morality. It should be noted that, the social values are "the values" based on evaluation emphasizing on according with people's interests and values, having great difference in the values which is based on the "widely accepted" and emphasized for people to understand and accept. (Jepperson, 1991). Chuhong Zeng (2008) pointed out in his paper, companies can make their actions conform to social norms, adherence to shared values and moral standards, using universal professional standards to achieve legitimacy of enterprise institutional norms.

\section{THE DIMENSIONS OF INSTITUTIONAL NORMS FOR PLACE BRANDING}

DiMaggio and Powell(1983) both insist that organizational field refers to the organizations that gather or group together, including important suppliers, resources, goods consumers, regulative institutions and also a recognized field of institution life constituted by other organizations that provide similar products and service. The politics, economy, law and culture in the field makes up its margin, but the interaction between the organizationcommunities inside is more frequent than outside, which is particularly important for the existence and development of the organizations in the field. Therefore, organizational field can be a place or a country in a sense which provides an institution background for the operation of the organizations in the field, and exerts certain influence on the organizational conduct structure. That's to say, the specific institution environment forms the background of the institution norms restraining organization behaviors. In case any organization violates the principle and values of the institutional norms, the organization will face a threat in the legitimacy of its existence and development, and it will be hard for the organization to maintain or organize any activities.

By literature review, the thesis will adopt the definition of institutional norms dimension raised by Chuhong Zeng (2008) ----prevailing social norms, shared values and moral standards, and universal professional standards. Once an organizational field is established, it develops a strong power to get the organizations in the field increasingly similar in structure and behavior, generate common concepts or shared thinking mode, and gradually form a uniform social evaluation standards and moral criterion, meanwhile, the organizations will also accept the social norms in the formation and generalization of the professional knowledge. The process of place branding requires enterprises in the place to follow the shared values and moral standards to acquire socially accepted comment, so as to pursue the existence and development of the place brand. Therefore, the dimension of the institutional norms for place branding is assumed as the prevailing social norms, shared values, shared moral standards and universal professional standards, as shown in Fig.1: 


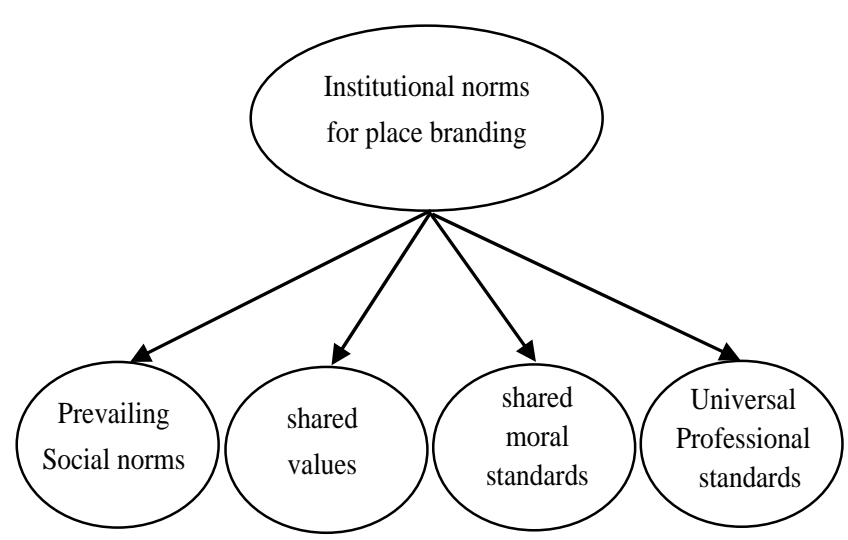

Figure 1. The dimensions model of institutional norms for place branding.

Among this, the prevailing social norm is a common sense, restraining the behaviors of the organization and individuals by legal mechanism (Meyer, 1977) to prevent the improper behaviors of any enterprises in the place. The shared values and moral standards that are internalized in place forms a common thought of the enterprises in the place, and it's also the evaluation criterion of the institution environment on the enterprises. It aims to generate a common thinking logic among the enterprises and allow them to following the shared moral standards to get a consistent overall behavior in the place. The universal professional standards serves to help an occupational group to standardize their work environment and method, control product and output, and thus build a cognitive basis and legal basis for their occupation (DiMaggio\& Powell(1983),Larson (1977), Collins (1979)). That's to say, the universal professional standards aims to build a consistent and standard action procedure to get a uniform result, based on the common cognitive structure of the enterprises in the place.

\section{CONCLUSIONS}

\section{A. Conclusions}

Place branding now has become inevitable product of place economic development, and it's the strategic choice to maintain a place competitive advantage. The public goods attributes of place brand make the place's enterprises in the sharing of economic benefits which come from the place brand asset will ignore the constraint of institutional norms for place banding, and violate social morality from the comparative case analysis, affecting formation of institution norms for place branding. Therefore, the purpose of this paper is to recognize and dig out the dimensions composition of institutional norms for place branding based on normalization factors of institutional theory.

\section{B. Implications and Contributions to Theory}

Contribution to the theory, from a theoretical perspective of institution we can not only clarify the dimensions of institutional norms for place branding, but deepen the development of place branding. The exploratory study found that the dimensions of place branding institutional norms includes prevailing social norms, shared values, shared moral standards, and universal professional standards. Among them, the prevailing social norms are a social common sense accumulated by the history and cultural heritage, restraining corporate behavior in the place, and promoting the conformity of corporate behavior for place branding. Shared values and moral standards are the results of place shared thoughts and internalized ideas, and are also the results of forming the institutionalized evaluation criteria in the process of building place brand. Universal professional standards are acquired by companies in the place, which can keep the development of enterprises consistent, continuous, efficient, and then jointly promoting the process of place branding.

On the management of revelation, In order to survive and succeed, the place's governments, businesses and other stakeholders get resources rationally under the institutional environment pressure, so that they can differentiate from the competitors in personality identity and market association. However, the constraint of institutional norms makes the organizations effectively choose their behavior and structure. For example: When companies pursue individual economic interests and violate the institutional norms, they will lose the resources advantage of legitimacy and get punished. Therefore, emphasis on recognizing the dimensions of place branding institutional norms can help to promote enlightenment and moral values cognition of stakeholders inside the place, to develop the habit and cultivate the awareness of the role. And forming a "Community" relied on trust, sharing and cooperation to solve the problem of collaboration makes institutional norms become the endogenous power that driving sustainable development of place branding.

According to research result, the enterprises shall abide by the prevailing social norm, shared values and moral standards and the universal professional standards in the process of place branding. That is because place branding is a long process of cultivation and its development course is the process of institutional norms, while institutional norms restricts the behaviors of the enterprises in the region. That is why it can be put that regional branding can achieve a sustainable development only by making sure the general social norm, shared values, common moral standards and the general professional standards are accepted and internalized by the enterprises in the field.

\section{Limitations and Further Research Directions}

The constitutional dimension of the regional branding system specification has been explored in the thesis after literature review, while it fails to further measure the effectiveness of the dimension by measurement scale. Therefore, the future research will focus on the accuracy and universality of verification model, and furthermore, in view of tragedy of the commons arising from the frequent enterprise opportunism in the region, the future research shall also cover how the system specification can push the enterprises to participate in regional branding construction. 


\section{ACKNOWLEDGEMENTS}

We are grateful for the financial support of the 2012 National Natural Science Foundation of China (71262024), and Foundation of the Ministry of Education of China for Returned Scholars offered by Ministry of Education of China (Gan Jiao Cai zi [2009]135), and the Soft Science Research Project (2009DR04400) offered by Jiangxi Provincial Department of Science and Technology, and the Social Science Planning Project (13GL09) offered by Jiangxi Provincial Association of Social Sciences, and the 2015 Postgraduate Innovation Foundation Project offered by Jiangxi Province Education Department.

\section{REFERENCES}

[1] Anholt, S. 2010. Definitions of place branding-Working towards a resolution. Place Branding and Public Diplomacy, 6(1): 1-10.

[2] Allen.G. 2007. Place branding: New tools for economic development. Design Management Review, 18(2):60 -681.

[3] Dimaggio F J \& Powell W W. 1983.The Iron Cage RevisitedInstitutional Isomorphism and Collective Rationality in Organizational Fields. American Sociological Review, Vol.48: 147 160.

[4] Kaplan, M. D. \& Yurt, O. \& Guneri, B. \& Kurtulus, K. 2010. Branding places: Applying brand personality concept to cities, European Journal of Marketing, Vol.44, No.9/10.

[5] Kavaratzis, M. 2005. Place branding: A review of trends and conceptual models. The Marketing Review, 5(4): 329-342.

[6] Kotler, P. \& Haider, D. H. \& Rein, I. 1993. Marketing places: attracting investment, industry, and tourism to cities, states, and nations. Marketing Places Attracting Investment Industry \& Tourism to Cities States \& Nations, Vol.3:80-81.
[7] Jepperson R.L. 1991 Institutions, institutional effects, and institutionalism. The New Institutionalism in Organizational Analysis.

[8] Meyer, J. W. \& Rowen, B. 1977. Institutionalized Organizations: Formal Structure as Myth and Ceremony. American Journal of Sociology, 83(2): $340-363$.

[9] Meyer, J. W. \& Scott, W. R. 1983. Organizational Environment: Ritual and Rationality . Beverly Hills, CA: Sage.

[10] Pedersen, S.B. 2004. Place branding: Giving the region of Oresund a competitive edge. Journal of Urban Technology, Vol.11, No.1.

[11] Rahbar, E. \& Wahid, N. A. 2011. Investigation of green marketing tools' effect on consumers' purchase behavior. Business Strategy, vol. 12(2):73-83(11)

[12] Rainisto, S. K. 2003. Success Factors of Place Marketing: a study of place marketing practice in Northern Europe and the USA. Institute of Strategy and International business.

[13] Govers, R. \& Go, F. 2009. Place branding: Global, virtual and physical identities, constructed, imagined and experienced.

[14] Scott, W. R. 2005. Institutional theory: Contributing to a theoretical research program. Great minds in management: The process of theory development, 460-484.

[15] Scott, W. R. 1995. Institutions and Organizations. Thousand Oaks, CA: Sage.

[16] Scott, W. R. 1987.The Adolescence of Institutional Theory. Administrative Science Quarterly, 32(4): 493 -511.

[17] Vishwas, Maheshwari \& Ian, Vandewalle \& David Bamber. 2011. Place branding's role in sustainable development. Journal of Place Management and Development, Vol. 4,198 - 213.

[18] Zaichkowsky, J. L. \& Parlee, M. \& Hill, J. 2010. Managing industrial brand equity: Developing tangible benefits for intangible assets Industrial Marketing Management, 39(5):776-783.

[19] Chuhong, Zeng. \& Renhong, Zhu. \& Kongyue, Li. 2008. Legitimacy of the organization based on Strategic Perspective. Foreign Economics and Management, Vol. 2. 